\title{
Uses and microbiological quality of fresh cow's milk sold in three markets in South Benin
}

\author{
Oumarou DJOBO ${ }^{1}$, Haziz SINA ${ }^{1}$, Pocoun Damè KOMBIENOU ${ }^{2}$, Wilfrande Morenikè \\ DJENONTIN ${ }^{1}$, Virgile AHYI ${ }^{3}$, Issaka Youssao Abdou KARIM ${ }^{4}$, Adolphe ADJANOHOUN ${ }^{2}$, \\ Manuel RENDUELES ${ }^{5}$ and Lamine BABA-MOUSSA ${ }^{1 *}$
}
${ }^{1}$ Laboratory of Biology and Molecular Typing in Microbiology, Department of Biochemistry and Cell Biology, Faculty of Sciences and Technology, University of Abomey-Calavi, Benin.
${ }^{2}$ National Agronomic Research Institute of Benin, 01 BP 884 Cotonou, Republic of Benin.
${ }^{3}$ Department of Chemical Engineering, IRGIB-Africa, Benin.
${ }^{4}$ Animal Biotechnology and Meat Technologies Laboratory, Animal production Department, EPAC, University of Abomey-Calavi, Benin.

${ }^{5}$ Department of Chemical and Environmental Engineering, Polytechnic School of Engineering, Gijón Campus, University of Oviedo, Spain.

Received 13 August 2021; Accepted 27 September 2021

\begin{abstract}
The aim of this study was to determine the common uses and evaluate the microbiological safety of raw milk sold in southern Benin. To determine the different uses of raw milk, 345 individuals were surveyed in three locations (Allada, Ouidah, and Zongo). Per location, 115 individuals were randomly sampled. For the microbial analysis, milk samples were collected from the three targeted locality in southern Benin (Allada, Ouidah, and Zongo). Our data shows that the mean values (CFU/ml) of the analyzed samples vary according to the research organisms. Thus, it is recorded $1.8 \times 10^{8}$ for total aerobic mesophilic flora (TMC), $4.0 \times 10^{7}$ for fecal coliforms (FC), $3.5 \times 10^{7}$ for Escherichia coli, $2.8 \times 10^{7}$ for total coliforms (TC), $2.1 \times 10^{7}$ for Fecal Streptococci (FS), $1.6 \times 10^{7}$ for yeasts and molds (YM), $1.7 \times 10^{7}$ for sulfur reducing anaerobic bacteria (SRA) and $1.2 \times 10^{7}$ for Staphylococcus spp. None of the milk samples contained Salmonella spp. Globally, milk samples had important bacterial load with the highest values for those collected from Zongo and Ouidah. It can be said that raw milk sold in the Southern Benin's markets does not comply with good hygienic practice rules in milking, storage, transportation and sale. Thus, raw cow milk sold presents a serious health risk for potential consumers.
\end{abstract}

Key words: Raw milk, microbiological quality, food safety, pathogens, Benin.

\section{INTRODUCTION}

The consumption of fresh milk in Benin is still relatively

moderate and the government's strategies for the

${ }^{*}$ Corresponding author. E-mail: laminesaid@yahoo.fr.

Author(s) agree that this article remain permanently open access under the terms of the Creative Commons Attribution License 4.0 International License 


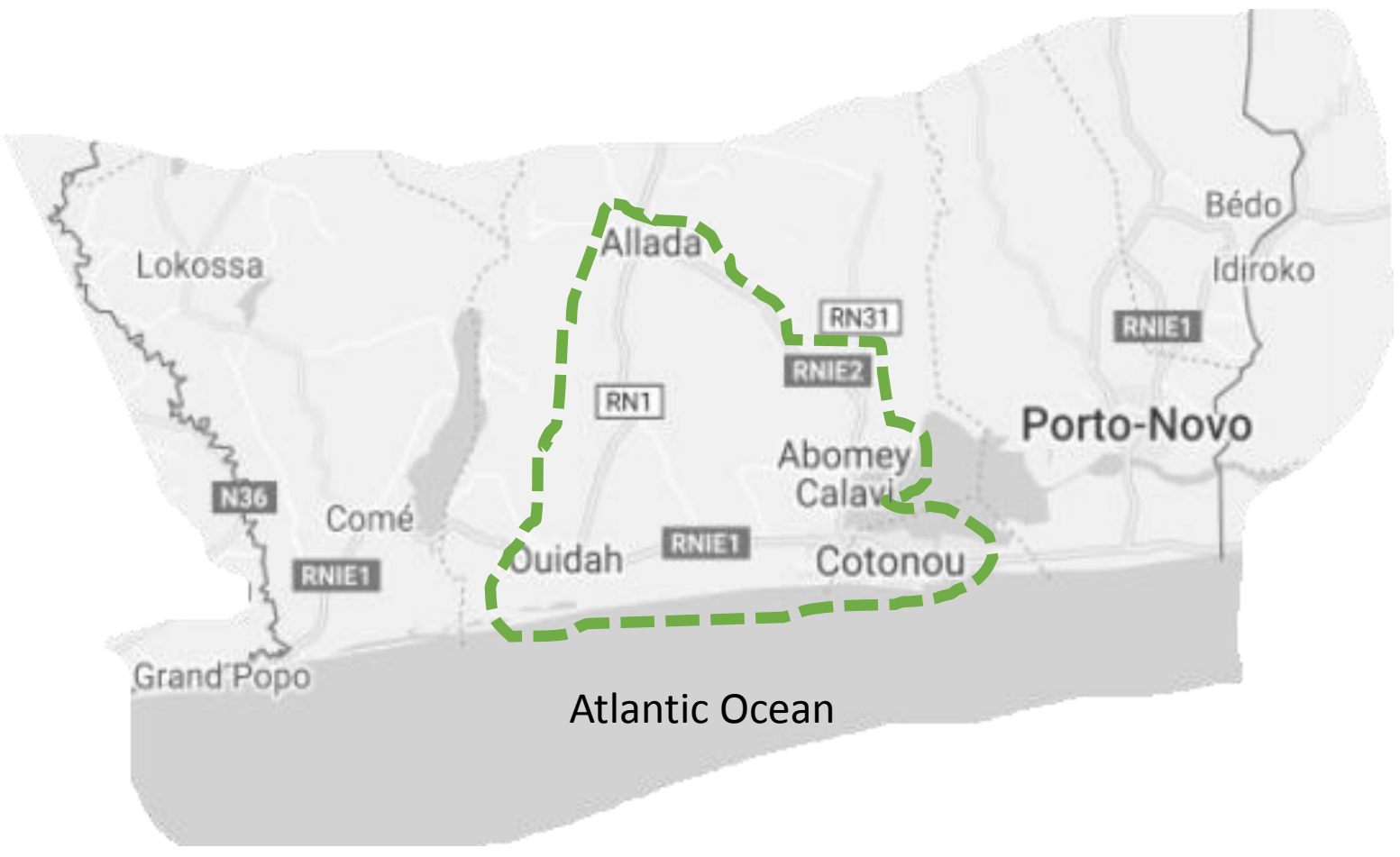

Figure 1. Map of south Benin showing the study area (dotted line).

development of the dairy sector have not succeeded in boosting it considerably. Thus, imported milk occupies an important part of the dairy market (Anihouvi et al., 2019). However, due to the relatively high price of industrial fresh milk and the lack of storage facilities, most consumers buy fresh milk, generally milked in the morning, the same day. While it is up to the manufacturer to ensure the safety and suitability of milk produced on factory farms and dairy industries, local ranchers are not making this a priority. Fresh milk as drawn from a healthy cow may contains a low microbial load which may increase in some conditions between milking and selling in local markets (Knight-Jones et al., 2016; VelázquezOrdoñez et al., 2019). It is important that the government's strategies for the development of the dairy sector include direct collaboration with traditional producers in order to give them basic training in good hygiene practices and in situ quality control. To this end, data on the quality of fresh milk, for which urban demand continues to grow, are important to alert the authorities and producers and help them to set up guides to good hygiene practices, in terms of collection and storage. To our knowledge, the most recent data on the microbiological quality of fresh milk are those of Farougou et al. (2011). These authors carried out their studies in northern Benin targeting two municipalities with large dairy production.

Although, the microbial load of freshly milked milk can be decreased and the multiplication of the bacteria prevented by using clean containers and refrigerating (Bekuma and Galmessa, 2018), this is not customary in Benin. Milk is not refrigerated and barely heated between milking zones and transportation to the markets. This study was undertaken to examine the conditions on which local raw milk is stored, transported, sold and consumed and its microbiological quality as it is currently sold to consumers in local markets in South Benin.

\section{MATERIALS AND METHODS}

\section{Survey on milk uses}

A questionnaire has been addressed to milk consumers to assess milk supply, transport, storage, preservation and treatment before consumption. Stratified simple random sampling has been adopted where the study area (Figure 1) was divided into three zones: Zongo (local market at Cotonou), Allada and Ouidah at West and north of Cotonou respectively. The three zones have been selected for their importance (relative) of milk marketing. Simple random sampling was then applied to each zone (Taherdoost, 2016). A total of 345 individuals were surveyed at the rate of 115 individuals per zone.

\section{Sample collection}

A total of 387 raw cow milk samples were collected and analyzed from 3 local dairy markets between January 2019 and December 2020. Sample were randomly collected at three zones: Zongo (local market at Cotonou), Allada and Ouidah at west and north of Cotonou respectively (Figure 1). Samples were collected in the late 
Table 1. Media and conditions used for the isolation of germs in milk.

\begin{tabular}{llcc}
\hline Targeted microorganisms & Medium & $\begin{array}{c}\text { Temperature } \\
\left({ }^{\circ} \mathbf{C}\right)\end{array}$ & $\begin{array}{c}\text { Incubation } \\
\text { time (h) }\end{array}$ \\
\hline Total aerobic mesophilic flora & Plate count agar (Oxoid) & 30 & 72 \\
Total coliforms & Brilliant Green Lactose Bile Broth (BioRad) & 30 & 72 \\
Fecal coliforms & & 44 & 48 \\
Salmonella spp. & Rappaport-Vassiliadis (Oxoid), & 37 & 24 \\
Yeasts and molds & Salmonella-Shigella (Oxoid) & 37 & 24 \\
Sulfur reducing anaerobic bacteria & Dichloran Rose Bengale Chloram-phénicol (Oxoid) & 30 & 72 \\
Staphylococcus spp. & Trypticase Sulfite Neomycin (BioRad) & 37 & 48 \\
Escherichia Coli & Baird Parker (Oxoid) & 37 & 48 \\
\hline & Eosin methylene blue (Oxoid) & 37 & 24 \\
\hline
\end{tabular}

morning and performed to reflect the relative quality of individual zones, based on data. They were transported as bought in cans to the laboratory. Approximately $100-200 \mathrm{ml}$ milk was aseptically sampled from milk cans bought from each individual zone into a sterile bottle. Samples were directly used after withdrawal and the rest cooled at $4^{\circ} \mathrm{C}$ (within $30 \mathrm{~min}$ ). Milk is collected by farmers in small plastics and brought together into $25 \mathrm{~L}$ water buckets (usually). The retailers then bring their 1.5 or $1 \mathrm{~L}$ plastics cans where they buy the fresh milk. The milk is brought to markets in this final container and sold as is to the final consumer.

\section{Microbiological analysis}

All samples and media preparation and germs counting were performed according to international standards (ISO 7218, 2007; Lahou et al., 2012; Centre for Food Safety Food and Environmental Hygiene Department, 2014). Decimal dilutions of the milk samples up to $10^{-7}$ have been made using buffered peptone water. The main selective media used for the isolation and enumeration of colonies are described in Table 1. The isolation and enumeration of total aerobic mesophilic flora (TMC), total coliforms (TC), fecal coliforms (TC), sulfite-reducing anaerobic bacteria (SRA), Staphylococcus ssp., fecal Streptococci (FS), yeasts and molds (YM) were performed according to international standards.

The TAM count was carried out after appropriate dilutions of the sample in the buffered peptone water broth then inoculation on Plate Count Agar (PCA) medium and incubated at $30^{\circ} \mathrm{C}$ for $72 \mathrm{~h}$ (ISO 4833, 2013). The count of total coliforms is carried out on Brilliant Green Lactose Bile medium and incubated at $30^{\circ} \mathrm{C}$ for total coliforms and at $44^{\circ} \mathrm{C}$ for fecal coliforms, the count of red colonies is carried out after $24 \mathrm{~h}$ of incubation (AFNOR NF V08-060, 2009).

For the detection of Salmonella, a pre-enrichment stock suspension (10 ml of milk in $90 \mathrm{ml}$ of sterile diluent) was incubated for $18 \mathrm{~h}$ at $37^{\circ} \mathrm{C}$. The resulting culture was inoculated with Rappaport-Vassiliadis broth at $41.5^{\circ} \mathrm{C}$ for $24 \mathrm{~h}$. These cultures are then incubated in XLD agar at $37^{\circ} \mathrm{C}$ for $24 \mathrm{~h}$ (ISO 6579-1, 2017).

For the enumeration of yeasts and molds, $0.1 \mathrm{ml}$ of the decimal dilutions is placed on the surface of the petri dishes pre-cast with DRBC agar and incubated at $25^{\circ} \mathrm{C}$ for three days in the dark (ISO 21527-1, 2008).

For the detection of Staphylococcus spp., Baird - Parker agar, a partially selective medium which exploits the capacity of staphylococci to reduce tellurite to tellurium and to detect the presence of lecithinase from the lecithin of the egg, was inoculated with $0.1 \mathrm{ml}$ of dilution then incubated at $37^{\circ} \mathrm{C}$ for $48 \mathrm{~h}$ (ISO 6888-1, 1999).

For Escherichia coli, EMB plates were streaked by $0.1 \mathrm{ml}$ sample then the plates were incubated at $37^{\circ} \mathrm{C}$ for $24 \mathrm{~h}$. Large, blue-black colonies with a shiny metallic green appearance are counted.

\section{Statistical analysis}

Contingency tables and independence test of the $\chi^{2}$ have been performed on the survey data. A significance level of 0.05 were used. Analysis of variance (ANOVA) for the comparison of means on log-transformed data was performed on microbiological parameters. Correlations analyses between different microbiological parameters were also performed on log-transformed data. All statistical analyses were performed using $R$ software version 4.0.1 (R Core Team, 2017) and Rstudio version 1.3.959 (RStudio Team, 2020). A significance level of 0.05 were used.

\section{RESULTS}

\section{Milk uses}

The diagram of Figure 2 represents the market chain of fresh milk in the study area. Fresh and fermented milk are provided by areas around Cotonou, namely, Ouidah ( $28 \mathrm{~km}$ at west Cotonou) and Allada ( $50 \mathrm{~km}$ at north Cotonou). The herders collect the milk in $25 \mathrm{~L}$ cans in the Allada and Ouidah zones. Early in the morning, the resellers go from one herd to the other to buy the milk which they load in 1 or $1.5 \mathrm{~L}$ plastics cans. The milk is then transported as is from these areas to the points of sale in Allada, Ouidah and Zongo in taxi (in motorcycle or car). The milk sold in Zongo therefore comes from Ouidah and/or Allada. Some Ouidah resellers, especially those who buy fresh milk for cheese making, also get supplies from Allada where milk is apparently more available. The end consumers will buy the milk in the market exclusively.

Throughout the milk marketing chain, particular attention has been paid to the hygiene of the containers used for storage and transport. At the level of the breeders, the milking takes place with utensils that only undergo a simple washing and not each time before milking. The cans and bowls used for storage are also simply washed. The milk is stored at room temperature. The resellers bring the cans where they transfer the milk, 


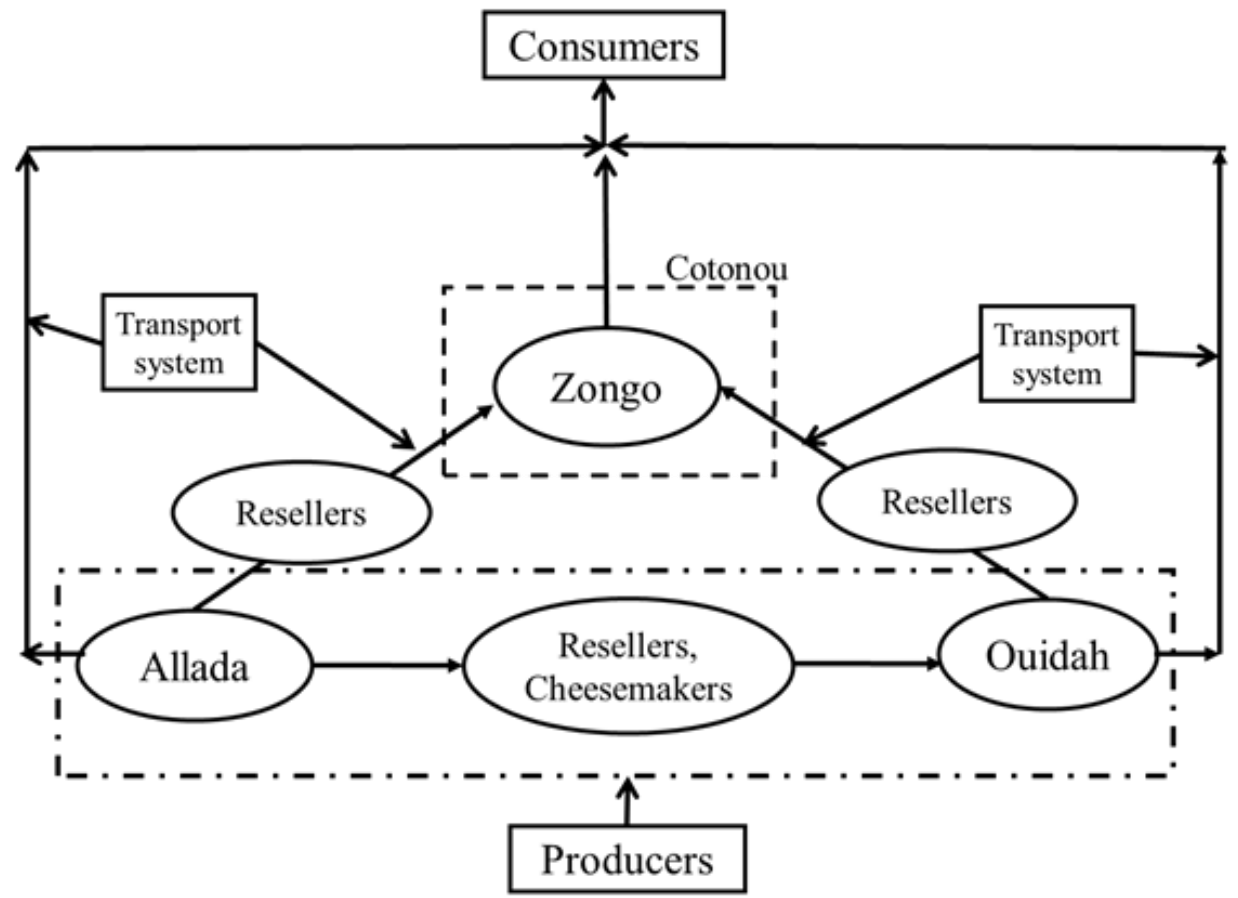

Figure 2. Diagram of the milk marketing chain in the study area.

Table 2. Cross tabulation of Zone vs. Form on which milk is sold. Cheese means sold for cheesemaking.

\begin{tabular}{lcccc}
\hline & Cheese & Fermented & Fresh & Total \\
\hline Allada & 48 & 10 & 57 & 115 \\
$\% r$ & 41.74 & 8.70 & 49.57 & 100.00 \\
$\% c$ & 59.26 & 9.62 & 35.63 & 33.33 \\
Ouidah & 33 & 18 & 64 & 115 \\
$\% r$ & 28.70 & 15.65 & 55.65 & 100.00 \\
$\% c$ & 40.74 & 17.31 & 40.00 & 33.33 \\
Zongo & 0 & 76 & 39 & 115 \\
$\% r$ & 0.00 & 66.09 & 33.91 & 100.00 \\
$\% c$ & 0.00 & 73.08 & 24.38 & 33.33 \\
Total & $\mathbf{8 1}$ & $\mathbf{1 0 4}$ & $\mathbf{1 6 0}$ & $\mathbf{3 4 5}$ \\
& 23.48 & 30.14 & 46.38 & 100.00 \\
& 100.00 & 100.00 & 100.00 & 100.00 \\
& 23.48 & 30.14 & 46.38 & 100.00 \\
\hline
\end{tabular}

$\% c=$ column percent; $\% r=$ row percent.

cans also only undergoing a simple washing. At the point of sale, the milk remains at room temperature.

The milk is bought fresh from breeders. However, in times of scarcity, the breeders collect the milk in the cans for 2 days (maximum 3 days) for the resellers who therefore recover it fermented. Table 2 shows the forms in which milk is sold to the consumers in the three zones. The columns $(\% c)$ and row $(\% r)$ percent are also shown. $41.74, \quad 8.70$ and $49.57 \%$ of milk are sold for
Table 3. Cross tabulation of user vs. treatment.

\begin{tabular}{lcccc}
\hline & Cold & Heat & None & Total \\
\hline Cheese maker & 0 & 82 & 0 & 82 \\
$\% r$ & 0.00 & 100.00 & 0.00 & 100.00 \\
$\% c$ & 0.00 & 51.57 & 0.00 & 23.77 \\
Consumer & 19 & 53 & 108 & 180 \\
$\% r$ & 10.56 & 29.44 & 60.00 & 100.00 \\
$\% c$ & 100.00 & 33.33 & 64.67 & 52.17 \\
Reseller & 0 & 24 & 59 & 83 \\
$\% r$ & 0.00 & 28.92 & 71.08 & 100.00 \\
$\% c$ & 0.00 & 15.09 & 35.33 & 24.06 \\
Total & 19 & 159 & 167 & 345 \\
$\% r$ & 5.51 & 46.09 & 48.41 & 100.00 \\
$\% c$ & 100.00 & 100.00 & 100.00 & 100.00 \\
\hline$\%$ & & & & \\
\hline
\end{tabular}

$\% c=$ column percent; $\% r=$ row percent.

cheesemaking, fermented and fresh respectively. The reason for separating milk sold fresh and for cheesemaking is the treatment it undergoes before consumption. At Ouidah, the proportions are 28.70, 15.65 and $55.65 \%$ respectively; while at Zongo they represent $0.00,66.09$ and $33.91 \%$ respectively. At Zongo, the milk is exclusively sold for direct consumption. As shown in Table 2, $30.14 \%$ of the milk is sold fermented and $46.38 \%$ is sold fresh in the three zones.

Table 3 shows the milk treatment by the different users in the three zones. The columns $(\% c)$ and row $(\% r)$ 
Table 4. Mean values for microbiological parameters (CFU/ml) .

\begin{tabular}{lcccc}
\hline Zone & Allada & Ouidah & Zongo & Mean \\
\hline Total mesophilic aerobic bacteria & $9.3 \times 10^{7 \mathrm{a}}$ & $1.7 \times 10^{8 \mathrm{~b}}$ & $2.7 \times 10^{8 \mathrm{c}}$ & $1.8 \times 10^{8}$ \\
Total coliforms & $2.6 \times 10^{7 \mathrm{a}}$ & $2.8 \times 10^{7 \mathrm{a}}$ & $3.0 \times 10^{7 \mathrm{c}}$ & $2.8 \times 10^{7}$ \\
Fecal coliforms & $<10^{6} \mathrm{a}$ & $8.6 \times 10^{7 \mathrm{~b}}$ & $3.4 \times 10^{7 \mathrm{c}}$ & $4.0 \times 10^{7}$ \\
Fecal streptococci & $<10^{6 \mathrm{a}}$ & $4.9 \times 10^{6 \mathrm{~b}}$ & $5.9 \times 10^{7 \mathrm{c}}$ & $2.1 \times 10^{7}$ \\
Sulfur reducing bacteria & $<10^{6 \mathrm{a}}$ & $2.4 \times 10^{7 \mathrm{~b}}$ & $2.8 \times 10^{7 \mathrm{c}}$ & $1.7 \times 10^{7}$ \\
Escherichia coli & $5.3 \times 10^{7 \mathrm{a}}$ & $5.4 \times 10^{7 \mathrm{~b}}$ & $<10^{6 \mathrm{c}}$ & $3.5 \times 10^{7}$ \\
Yeast and molds & $2.1 \times 10^{7 \mathrm{a}}$ & $1.1 \times 10^{7 \mathrm{~b}}$ & $1.7 \times 10^{7 \mathrm{c}}$ & $1.6 \times 10^{7}$ \\
Staphylococcus spp & $<10^{6 \mathrm{a}}$ & $5.2 \times 10^{6 \mathrm{~b}}$ & $3.1 \times 10^{7 \mathrm{c}}$ & $1.2 \times 10^{7}$ \\
Salmonella & $<10^{6 \mathrm{a}}$ & $<10^{6 \mathrm{~b}}$ & $<10^{6 \mathrm{c}}$ & - \\
\hline
\end{tabular}

"In the rows of the table, means with different letters $(a, b, c)$ are significantly different at the level considered (0.05).

Table 5. Correlations coefficients between the different microbiological milk quality parameters.

\begin{tabular}{lccccc}
\hline & TMC & TC & FC & FS & SRA \\
\hline TC & 0.835 & & & & \\
FC & 0.938 & 0.593 & & & \\
FS & 0.953 & 0.630 & 0.999 & & \\
SRA & 0.955 & 0.635 & 0.999 & 1.000 & \\
STAPH & 0.993 & 0.896 & 0.889 & 0.909 & 0.912 \\
\hline
\end{tabular}

TMAF $=$ Total aerobic mesophilic flora; $\mathrm{TC}=$ total coliforms; $\mathrm{FC}=$ Fecal coliforms; SRA = Sulfur reducing anaerobic bacteria; STAPH = Staphylococcus spp.

percent are also shown. Due to the process of traditional cheese making which involves heating, $100 \%$ of cheesemakers heat their milk; while $29.44 \%$ of the direct consumers heat up the milk before use; $60.00 \%$ use it as they bought it and $10.56 \%$ refrigerate it. None of the resellers refrigerate their milk before selling or the unsold milk; while $28.92 \%$ heat it up before selling and $71.08 \%$ sell it as they buy from the farms.

\section{Microbiological quality}

The results of the microbiological analyses of the raw milk samples are summarized in Table 4 . In general, the mean value of total mesophilic aerobic bacteria is very high in the three zones. However, the value is higher in central Cotonou market (Zongo, $2.7 \times 10^{8} \mathrm{CFU} / \mathrm{ml}$ ) than in Ouidah $\left(1.7 \times 10^{8} \mathrm{CFU} / \mathrm{ml}\right)$, which in turn is higher than Allada $\left(9.3 \times 10^{7} \mathrm{CFU} / \mathrm{ml}\right)$. The means are statistically different $(p<0.001)$. A similar mean total coliform was found in Allada and Ouidah ( $p=34.6 \%)$. Higher count was found for samples from Zongo $\left(3.0 \times 10^{7} \mathrm{CFU} / \mathrm{mL}\right)$. Fecal coliforms were not found in sample from Allada but their count is high in samples from Ouidah $\left(8.6 \times 10^{7}\right.$ $\mathrm{CFU} / \mathrm{ml})$ and Zongo $\left(3.4 \times 10^{7} \mathrm{CFU} / \mathrm{ml}\right)$, Ouidah having a higher count. Fecal Streptococci were not found in sample from Allada but their count is high in samples from Ouidah $\left(4.9 \times 10^{6} \mathrm{CFU} / \mathrm{ml}\right)$ and Zongo $\left(5.9 \times 10^{7}\right.$ $\mathrm{CFU} / \mathrm{ml}$ ), Zongo having a higher count. Sulfur reducing bacteria were not found in sample from Allada but in samples from Ouidah $\left(2.4 \times 10^{7} \mathrm{CFU} / \mathrm{ml}\right)$ and Zongo $(2.8$ $\times 10^{7} \mathrm{CFU} / \mathrm{ml}$ ), Zongo having a higher count.

E. coli were not detected in samples from Zongo but in samples from Ouidah $\left(5.4 \times 10^{7} \mathrm{CFU} / \mathrm{ml}\right)$ and Allada (5.3 $\times 10^{7} \mathrm{CFU} / \mathrm{ml}$ ), Ouidah having a slightly higher count. Yeast and molds have been detected in the samples from the three zones. Higher count was obtained at Allada (2.1 $\left.\times 10^{7} \mathrm{CFU} / \mathrm{ml}\right)$ followed by Zongo $\left(1.7 \times 10^{7} \mathrm{CFU} / \mathrm{ml}\right)$ and then by Ouidah $\left(1.1 \times 10^{7} \mathrm{CFU} / \mathrm{ml}\right)$. Staphylococcus spp. were not detected in samples from Allada but in samples from Ouidah $\left(3.1 \times 10^{7} \mathrm{CFU} / \mathrm{ml}\right)$ and Zongo $\left(5.2 \times 10^{6}\right.$ $\mathrm{CFU} / \mathrm{ml}$ ), the later having a higher count. Salmonella was absent in all samples (Table 4).

The results of the correlation analyses between pairs for the different microbiological parameters are summarized in Table 5. Results for salmonella were excluded from the correlation analyses because they were not present in the samples. High correlations were found between TMC and all other microorganisms except YM. There was also a high correlation between sulfur reducing bacteria and fecal coliforms (0.999) and fecal streptococci (1.000), the late correlation being the highest. Note that, also, yeast and molds and E. coli were not included in the correlation analysis because their presence was not constant among the three sampled zones. E. coli were not detected in samples from Zongo. Fecal coliforms, fecal Streptococci, sulfur reducing bacteria and Staphylococcus spp. were not present in sample from Allada.

\section{DISCUSSION}

The "traditional" milk market chain in the studied area lacks proper planning, collection and distribution facilities. 
The milking conditions, the means of storage, transport and marketing do not make it possible to ensure good control of the hygienic quality of the milk sold in the studied local markets. A chi-square test of independence was performed to examine the relation between the zones and the form in which milk is sold and between the use made of the milk and the treatment before that use.

The relation between the form and the zone was significant, $\chi^{2}(4, N=345)=125.75, p<0.001$. The form in which milk is sold (mainly in Zongo) is more likely to depend on to where it comes from. In the same way, there were a significant relationship between the zones and milk preservation technics. Consumers in Zongo were more likely than the others to heat or refrigerate their milk, $\chi^{2}(4, N=345)=41.67, p<0.001$. The small portion of users $(5.51 \%$, Table 2$)$ who use refrigeration to preserve their milk could be explained by the fact that most milk consumers cannot afford a refrigerator and that consumers who can would buy industrial milk in supermarkets as an important part of milk is imported in Benin (Sombo, 2013). Naturally fermented milk can't be heated as this would affect its taste and cook the curd. Traditionally, milk is consumed mixed to other foods (porridge and other local meals). The time it takes to go through the sales chain without any treatment should allow microorganisms to grow rapidly in the milk. This subjects the milk consumed in Zongo to a lower microbiological quality. This is proved by the second part of this study.

The dairy policy is not a priority for the Beninese government, the implementation of the policy for the promotion and valuation of livestock products being based on livestock development programs (Dutilly et al., 2020). However, with growing interest, these policies should include collaboration with traditional marketers of milk and dairy products. This collaboration should be based on training aimed at improving the quality of milking, storage and transport of milk and publicizing the dangers that can be represented by the consumption of poor-quality milk. Unsanitary conditions or practices during the pre- and post-pasteurization processes and/or a deficiency in pasteurization have been found to conduct to high level of contamination (Martin et al., 2018). Furthermore, a study conducted in pasteurization centers in Africa (Owusu-Kwarteng et al., 2020) and in Brazil (Silva et al., 2010), suggest that pasteurization is not the only critical step for improving the microbiological quality of milk products (Pappa et al., 2019; Enayaty-Ahangar et al., 2021). Hence, the importance to integrate all the market chain in the promotion of the quality of milk and dairy products.

The European Union requirements for raw milk include an upper limit of $5 \mathrm{log} \mathrm{CFU} / \mathrm{ml}\left(10^{5} \mathrm{CFU} / \mathrm{ml}\right)$ for the total plate count (European Commission, 2004; Marri et al., 2020) for satisfactory quality of raw milk. In the three analyzed zones, the Total Mesophilic Count (TMC) load exceeds this microbiological criterion applicable to milks, although the ANOVA showed a significant difference between them $(p<0.05)$. The mean value for TMC $(1.8 \times$ $10^{8} \mathrm{CFU} / \mathrm{ml}$ ) is higher than that obtained by Kamana et al. (2014) in Rwanda's farms and collection centers. However, Aaku et al. (2004) in Botswana and Bonfoh (2002) in Bamako obtained a TMC range from 5.3 to 7.8 $\log \mathrm{CFU} / \mathrm{ml}\left(2 \times 10^{5}\right.$ to $\left.1.6 \times 10^{7} \mathrm{CFU} / \mathrm{ml}\right)$ and $8.1 \mathrm{log}$ $\mathrm{CFU} / \mathrm{ml}\left(1.3 \times 10^{8} \mathrm{CFU} / \mathrm{ml}\right)$ respectively. The results obtained for the TMC for Ouidah and Zongo are similar to those obtained by Farougou et al. (2011) in northern Benin. The total aerobic mesophilic flora being an indicator of the hygienic quality of raw milk, its presence in such large numbers indicates poor hygiene control during milking or of the equipment used in the transport and storage of raw milk (Clarence et al., 2009; Chorfi et al., 2020).

The results obtained for the total coliforms (TC) and fecal coliforms $(F C)$ in raw milk from Ouidah and Zongo are higher than those $\left(6.17 \times 10^{2} \mathrm{CFU} / \mathrm{ml}\right.$ and $9.24 \times 10^{2}$ $\mathrm{CFU} / \mathrm{ml}$ respectively) obtained by Farougou et al. (2011) in northern Benin. However, at Allada these germs were absent. Moreover, Kouamé-Sina et al. (2010) found in the Côte d'Ivoire that raw milk contained, on average, 5.5 log $\mathrm{CFU} / \mathrm{ml}$ coliforms in milk storage tanks at farms and 6.0 $\log \mathrm{CFU} / \mathrm{ml}$ during sale, while Swai and Schoonman (2011) found between 6.2 and $6.6 \mathrm{log} \mathrm{CFU} / \mathrm{ml}$ in retail raw milk in Tanzania.

Total coliforms were found in all milk samples analyzed. In addition, E. coli was detected in Allada and Ouidah; fecal coliforms and fecal streptococci were found in samples from Ouidah and Zongo. All values present are higher than those found by Farougou et al. (2011) in Northern Benin. El-Leboudy et al. (2014) reported mean total coliform counts of $3.28 \times 10^{2}-1.4 \times 10^{3} \mathrm{CFU} / \mathrm{ml}$ in Egypt with the dominant isolated coliforms of $8 \% \mathrm{E}$. coli. In Zimbabwe, E. coli counts of 1.78- $2.21 \log 10 \mathrm{CFU} / \mathrm{ml}$ were reported in milk samples by Chimuti et al. (2016).

Total coliforms and fecal coliforms are considered technical indicators for the general control of fecal contamination and cleaning systems, but it is above all fecal coliforms and E. coli which are the most effective indicators of the direct fecal contamination. Moreover, the existence of total coliforms would be an indicator of poor hygiene practices but not necessarily direct fecal contamination of milk (Meshref, 2013). The presence of these germs in milk could be of environmental origin (Martin et al., 2016).

Sulfur reducing bacteria were found in samples from Ouidah and Zongo $\left(2.4 \times 10^{7}\right.$ and $2.8 \times 10^{7} \mathrm{CFU} / \mathrm{ml}$ respectively) but not Allada. Our counts are higher than those found by Farougou et al. (2011) in northern Benin (3.8 CFU/ml) and lower than those found by Edward and Inya (2003) in Nigeria. Contamination by these bacteria may come from cow's intestine microflora, soil or from milkers themselves as carriers (Underwood et al., 2015; Owusu-Kwarteng et al., 2020). In milk analysis, sulfur reducing bacteria are also used as fecal contamination 
indicators. However, contamination by these bacteria can be minimized efficiently by good manufacturing practices (EFSA, 2005; Virpiranta et al., 2019).

Yeasts and molds were present in all samples at values higher than those found by Farougou et al. (2011) in northern Benin but much lower than those found by Edward and Inya (2003) in Nigeria. Yeasts and molds contamination is due mainly to milking and packing tools (Frank, 2007; Sørhaug, 2011). Yeasts and molds in milk may represent a potential health risk (Garnier et al., 2017) as they have been related to some disease due to milk (Fernández et al., 2015). However, they usually do not survive pasteurization (Elshrawy et al., 2019). Salmonella spp. were absent in all samples analyzed.

Staphylococcus spp. were found in samples from Ouidah and Zongo but not Allada. Our counts are lower than those found by Edward and Inya (2003) in Nigeria. $S$. aureus lives naturally in skin and mucous membranes of the nose and oropharynx of warm-blooded animals (Otto, 2010; Hanssen et al., 2017). It can be eliminated by simple pasteurization after which, nonetheless, some stains can keep their biological activity (Gayà and Calvo, 2018; Yu et al., 2020). Care must be taken regarding Staphylococcus particularly $S$. aureus because it has been known to be responsible for food poisoning outbreaks (De Buyser et al., 2001; Kadariya et al., 2014).

A correlation analysis has been performed between the microbiological parameters assessed (Table 3). Except for total coliforms, high correlation has been found between all the microbiological parameters, specially between total aerobic mesophilic count and the others parameters. Given that the total aerobic mesophilic indicate the global bacterial load in the milk, this correlation confirms the overall results obtained. Mainly, most of bacteria were present at high numbers. Furthermore, the high correlation between the fecal coliforms and fecal streptococci (0.999) and sulfur reducing bacteria (0.999) confirms the fecal contamination. On other hand, the relatively medium and high correlations between total coliforms (0.593) and fecal streptococci (0.630) and sulfur reducing bacteria $(0.635)$ and $S$. aureus $(0.896)$ would be due to the fact that these four bacterial groups were not present in samples from Allada. Note that however, the values for $S$. aureus obtained at Zongo and Ouidah are high, which could explain the relatively high correlation coefficient (0.896) observed.

\section{Conclusion}

Results of the study clearly indicated the low microbiological quality of raw milk sold in local markets. The milk samples analyzed from Zongo and Ouidah are generally unfit for human consumption. This is directly linked to the storage, preservation and transport steps in the milk market chain in the studied area. The presence of bacteria such as S.aureus, E. coli, yeasts and molds and some sulfur reducing bacteria (Clostridia for example) in raw milk is potentially dangerous and become a public health concern. Therefore, it is recommended that the dairy sector development plan involves training and guiding farmers and local milk sellers in good hygiene practices. Meanwhile, information on health hazards associated with contaminated raw milk should be extended to the public to allow the consumers to know the risks associated with the consumption of unhygienic raw milk.

\section{CONFLICT OF INTERESTS}

The authors have not declared any conflict of interests.

\section{REFERENCES}

Aaku EN, Collison EK, Gashe BA and Mpuchane S (2004). Microbiological quality of milk from two processing plants in Gaborone Botswana. Food Control 15(3):181-186.

AFNOR (2009). NF V08-060: Microbiology of food and animal feeding stuffs - Enumeration of thermotolerant coliforms by colony-count technique at $44^{\circ} \mathrm{C}$. Routine methods.

Anihouvi EL, Salih H, Anihouvi VB, Kesenkaş H (2019). Milk and dairy products production in Benin. Akademik Gida 17(4):508-516.

Bekuma A, Galmessa U (2018). Review on hygienic milk products practice and occurrence of mastitis in cow's milk. Agricultural Research and Technology 18(2):1-11.

Bonfoh B, Fané ATN, Coulibaly Z, Simbé C, Alfaroukh O, Nicolet J, Farah Z, Zinsstag J (2002). Qualité microbiologique du lait et des produits laitiers vendus en saison chaude dans le district de Bamako au Mali. In Actes du colloque international, Centre Suisse du 27-29 Août 2001. Abidjan: Editions Universitaires de Côte d'Ivoire, Côte d'Ivoire pp. 242-250.

Centre for Food Safety Food and Environmental Hygiene Department (2014). Microbiological Guidelines for Food (For ready-to-eat food in general and specific food items). In Food and Environmental Hygiene Department, Hong Kong. Available online: https://www.cfs.gov.hk/english/food_leg/files/food_leg_Microbiologica I Guidelines for Food e.pdf

Chimuti S, Midzi N, Njage PK, Mugadza DT (2016). Microbial species of safety concern in milk from informal processors in Harare, Zimbabwe. African Journal of Microbiology Research 10(32):1257-1262.

Chorfi K, Bendjemana K, Ayachi A, Mahdi F, Bouzidi NEA (2020). Effect of using treated wastewater on the bacteriological quality of raw cow's milk: A case of a farm in Northeastern Algeria. African Journal of Microbiology Research 14(8):436-446.

Clarence SY, Obinna CN and Shalom CN (2009). Assessment of bacteriological quality of ready-to eat foods in Benin City Metropolis, Nigeria. African Journal of Microbiological Research 3:309-395.

De Buyser ML, Dufour B, Maire M, Lafarge V (2001). Implication of milk and milk products in food-borne diseases in France and in different industrialized countries. International Journal of Food Microbiology 67:1-17.

Dutilly C, Alary V, Bonnet P, Lesnoff M, Fandamu P, De Haan C. (2020). Multi-scale assessment of the livestock sector for policy design in Zambia. Journal of Policy Modeling 42(2):401-418.

Edward KC, Inya IM (2003). The microbial quality of raw milk from four locations in Abia State, Nigeria. Journal of Pharmacy and Biological Sciences (IOSR-JPBS) 5(3):30-33.

European Food Safety Authority (EFSA) (2005). Opinion of the scientific panel on biological hazards on a request from the Commission related to Clostridium spp. in foodstuffs. EFSA Journal 199:1-65.

El-Leboudy AA, Amer AA, El-Mohsen SA (2014). Detection of some 
pathogenic organisms from dairy farm milk. Alexandria Journal of Veterinary Sciences 44:111-118.

Elshrawy T, Mohamed HA, Salem RM, ELbarbary HA, EL-Diasty EM (2019). Incidence of fungi in soft skimmed milk cheese from pasteurized milk and trials to control them. Benha Veterinary Medical Journal 37(1):91-96.

Enayaty-Ahangar F, Murphy SI, Martin NH, Wiedmann M, Ivanek R (2021). Optimizing pasteurized fluid milk shelf-life through microbial spoilage reduction. Frontiers in Sustainable Food Systems 140 p. https://doi.org/10.3389/fsufs.2021.670029

European Commission (2004). Regulation (EC) No 853/2004 of the European Parliament and of the Council of 29 April 2004 laying down specific hygiene rules for food of animal origin. Official Journal of European Union L 139:1-55.

Farougou S, Kpodékon TM, Sessou P, Youssao I, Boko C, Yèhouenou B, Sohounhloué D (2011). Qualité microbiologique du lait cru de vache élevée en milieu extensif au Bénin. In Actes du 3ème Colloque des Sciences, Cultures et Technologies de I'UAC-Bénin, 1-14. Available online at https://www.researchgate.net/publication/.

Fernández M, Hudson JA, Korpela R, de los Reyes-Gavilán CG (2015). Impact on human health of microorganisms present in fermented dairy products: an overview. BioMed Research International 2015 ID 412714,13 pages.

Frank J (2007). Milk and Dairy Products. In. Doyle M, Beuchat L (ed), Food Microbiology: Fundamentals and Frontiers. Washington DC: ASM Press.

Garnier L, Valence F, Mounier J (2017). Diversity and control of spoilage fungi in dairy products: An Update. Microorganisms 5(3):42. doi:10.3390/microorganisms5030042

Gayà $A$, Calvo $J$ (2018). Improving pasteurization to preserve the biological components of donated human milk. Frontiers in Pediatrics 6:288. doi:10.3389/fped.2018.00288

Hanssen AM, Kindlund B, Stenklev NC, Furberg AS, Fismen S, Olsen RS, Johannessen M, Sollid JU (2017). Localization of Staphylococcus aureus in tissue from the nasal vestibule in healthy carriers. BMC Microbiology 17(1):89. doi: 10.1186/s12866-017-09973.

ISO (1999). ISO 6888-1: Microbiology of food and animal feeding stuffs - Horizontal method for the enumeration of coagulase-positive staphylococci (Staphylococcus aureus and other species) - Part 1: Technique using Baird-Parker agar medium.

ISO (2007). ISO 7218: Microbiology of food and animal feeding stuffs General requirements and guidance for microbiological examinations.

ISO (2008). ISO 21527-1: Microbiology of food and animal feeding stuffs - Horizontal method for the enumeration of yeasts and moulds - Part 1: Colony count technique in products with water activity greater than 0.95 .

ISO (2013). ISO 4833-1: Microbiology of the food chain - Horizontal method for the enumeration of microorganisms - Part 1: Colony count at $30^{\circ} \mathrm{C}$ by the pour plate technique. Reviewed 2019 .

ISO (2013). ISO 4833-2: Microbiology of the food chain - Horizontal method for the enumeration of microorganisms - Part 2: Colony count at $30^{\circ} \mathrm{C}$ by the surface plating technique. Reviewed 2019.

ISO (2017). ISO 6579-1: Microbiology of the food chain - Horizontal method for the detection, enumeration and serotyping of Salmonella Part 1: Detection of Salmonella spp. AMD 1/2020.

Kadariya J, Smith TC, Thapaliya D (2014). Staphylococcus aureus and staphylococcal food-borne disease: an ongoing challenge in public health. Biomed Research International 2014: ID 827965, 9 pages. doi:10.1155/2014/827965

Kamana O, Siele C, Liesbeth J, Anastase K, Mieke U (2014). Microbiological quality and safety assessment of the Rwandan milk and dairy chain. Journal of Food Protection 77(2):299-307.

Knight-Jones TJ, Hang'ombe MB, Songe MM, Sinkala Y, Grace D (2016). Microbial contamination and hygiene of fresh cow's milk produced by smallholders in Western Zambia. International Journal of Environmental Research and Public Health 13(5):737.

Kouamé-Sina SM, Bassa A, Dadié A, Makita K, Grace D, Dje M, Bonfoh $B$ (2010). Analyse des risques microbiens du lait cru local à Abidjan (Côte d'Ivoire). Revue Africaine de Sante et Production Animale 8:3542.
Lahou E, Jacxsens L, Daelman J, Van Landeghem F, Uyttendaele M (2012). Microbiological performance of a food safety management system in a food service operation. Journal of Food Protection 75(4):706-716.

Marri N, Losito F, Le Boffe L, Giangolini G, Amatiste S, Murgia L, Arienzo A, Antonini G (2020). Rapid microbiological assessment in raw milk: validation of a rapid alternative method for the assessment of microbiological quality in raw milk. Foods 9(9):1186.

Martin NH, Trmčić A, Hsieh TH, Boor KJ, Wiedmann M (2016). The evolving role of coliforms as indicators of unhygienic processing conditions in dairy foods. Frontiers in Microbiology 7:1549.

Martin NH, Boor KJ, Wiedmann M (2018). Symposium review: Effect of post-pasteurization contamination on fluid milk quality. Journal of Dairy Science 101(1):861-870.

Meshref AMS (2013). Bacteriological quality and safety of raw cow's milk and fresh cream. Slovenian Veterinary Research 50(1):21-30.

Otto M (2010). Staphylococcus colonization of the skin and antimicrobial peptides. Expert Review in Dermatology 5(2):183-195.

Owusu-Kwarteng J, Akabanda F, Agyei D, Jespersen L (2020). Microbial safety of milk production and fermented dairy products in Africa. Microorganisms 8(5):752.

Pappa EC, Kondyli E, Samelis J (2019). Microbiological and biochemical characteristics of Kashkaval cheese produced using pasteurised or raw milk. International Dairy Journal 89:60-67.

R Core Team (2017). R: A language and environment for statistical computing. R Foundation for Statistical Computing, Vienna, Austria. URL https://www.R-project.org/.

RStudio Team (2020). RStudio: Integrated Development for R. RStudio, PBC, Boston, MA URL http://www.rstudio.com/.

Silva R, Cruz AG, Faria JA, Moura MM, Carvalho LM, Water EH, Sant'Ana AS (2010). Pasteurized milk: efficiency of pasteurization and its microbiological conditions in Brazil. Foodborne Pathogens and Disease 7(2):217-219.

Sombo MA (2013). Etude relative à la formulation d'un programme d'actions détaillé de développement de la filière lait au sein de I'UEMOA -Annexe 1 Rapport Bénin. CIRAD, 43 pages.

Sørhaug T (2011). Yeasts and molds. Spoilage molds in dairy products. Encyclopedia of Dairy Sciences 780-784.

Swai ES, Schoonman L (2011). Microbial quality and associated health risks of raw milk marketed in the Tanga region of Tanzania. Asian Pacific Journal of Tropical Biomedicine 1(3):217-222.

Taherdoost $H$ (2016). Sampling methods in research methodology; how to choose a sampling technique for research. How to Choose a Sampling Technique for Research. Available at SSRN: https://ssrn.com/abstract=3205035 http://dx.doi.org/10.2139/ssrn.3205035

Underwood WJ, Blauwiekel R, Delano ML, Gillesby R, Mischler SA, Schoell A (2015). Biology and Diseases of Ruminants (Sheep, Goats, and Cattle). Laboratory Animal Medicine pp. 623-694.

Velázquez-Ordoñez V, Valladares-Carranza B, Tenorio-Borroto $E$, Talavera-Rojas M, Varela-Guerrero JA, Acosta-Dibarrat J, Puigvert F, Grille L, Revello GA, Pareja L (2019). Microbial contamination in milk quality and health risk of the consumers of raw milk and dairy products. Nutrition in Health and disease-our challenges Now and Forthcoming time. Mózsik G, Figler M. (Ed). IntechOpen, DOI: 10.5772/intechopen.86182. Available from: https://www.intechopen.com/chapters/67214

Virpiranta H, Taskila S, Leiviskä T, Rämö J, Tanskanen J (2019). Development of a process for microbial sulfate reduction in cold mining waters-Cold acclimation of bacterial consortia from an arctic mining district. Environmental Pollution 252:281-288.

Yu T, Niu L, Iwahashi H (2020). High-pressure carbon dioxide used for pasteurization in food industry. Food Engineering Reviews 12(3):364380. https://doi.org/10.1007/s12393-020-09240-1 